\title{
MEMAHAMI TASAWUF IBNU ARABI DAN IBNU AL FARID: \\ Konsep al Hubb Illahi, Wahdat al Wujud, Wahdah al Syuhud dan Wahdat al Adyan
}

\author{
Muhammad Robith Fuadi \\ Universitas Islam Negeri Maulana Malik Ibrahim Malang \\ Telp:081553420066 \\ email: assidariji@yahoo.com
}

\begin{abstract}
Sufis underwent a different path towards nature. They did not use reason and ratio to arrive at the nature. However reason is not the only way to reach the nature since there are things beyond reason in life. The paths of the Sufis like kashef, dzauq, 'iyan, musyahadah and others are considered vague, with no definite boundaries and rules, even mixed with dreams, fantasy or wishful thinking. Yet such media are able to lead human solving something which cannot be solved by reasons and the laws of physics. This paper examines the ideas of two major figures in tasawuf i.e. Sufism of Ibn Arabi and Ibn al-Farid, who lives in the sixth and seventh century of Hijri. Three important notions of both figures include divine love, the essence of God and the similar substantive nature of religion.
\end{abstract}

Kaum sufi menapaki jalan yang berbeda menuju hakikat. Mereka tidak menggunakan akal dan rasio untuk sampai pada hakikat. Akan tetapi akal bukan satu-satunya jalan menuju hakikat karena adanya hal-hal di luar jangkauan akal dalam hidup ini. Jalan yang ditempuh kaum sufi seperti kasyf, dzauq, 'iyan, musyahadah dan sebagainya dinilai samar, tidak mempunyai batasan dan kaidah pasti, bahkan bercampur dengan mimpi, khayalan atau angan-angan. Tapi media tersebut mampu menuntun manusia untuk memecahkan sesuatu yang tidak bisa dipecahkan oleh akal dan hukum-hukum fisika. Tulisan ini mengkaji gagasan-gagasan dua tokoh tasawuf besar yaitu Ibnu Arabi dan Ibnu al-Farid yang hidup pada abad keenam dan ketujuh Hijriah. Tiga gagasan 
penting kedua tokoh tersebut meliputi cinta Ilahi,(al hubb al Ilahi), hakikat wujud Allah (wahdat al Wujud) dan wahdat al adyan) hakikat kesamaan substantif agama.

Keywords: tasawuf, al hubb al Ilahi, wahdat al Wujud and wahdat al adyan

\section{Pendahuluan}

Tasawuf merupakan salah satu sisi kehidupan Islam yang unik dan menarik. Tasawuf mendapatkan perhatian yang serius dari para pemikir Islam dalam mengungkap kehidupan tokohnya, aliran-aliran dan pengaruhnya terhadap gaya hidup dan berfikir kaum muslim pada khususnya, dan manusia pada umumnya. Akan tetapi, pada realitanya tasawuf dianaktirikan dan tidak mendapatkan perhatian yang semestinya dari para pemikir Islam. Kendati demikian, Islam sebagai pemilik khazanah tasawuf, patut berbangga dan berterimakasih kepada para orientalis yang telah mencurahkan segenap tenaga dan pikirannya untuk mengkaji tasawuf secara intensif sehingga menghasilkan kajian-kajian tasawuf yang sangat berharga dan tak ternilai. Diantaranya Louis Massignon, R.A. Nicholson, Carlo Nallino dan Ignasio. Hal ini dilakukan tanpa ada tendensi untuk meremehkan beberapa kajian yang dilahirkan para pemerhati tasawuf dari kalangan pemikir Islam sendiri, seperti Prof. Dr. Abu al 'Ala Afifi yang mengulas kehidupan Ibnu Arabi dalam karyanya "The Mystical Philosophy of Muhyid Din Ibnu 'Arabi” dan Prof. Dr. Zaki Mubarok yang menyuguhkan kajian tentang pengaruh tasawuf terhadap perjalanan sastra, etika dan moral. Meskipun demikian, kajian tersebut belum representatif jika dibandingkan dengan kekayaan khazanah tasawuf yang begitu melimpah ruah (Hilmi, tt: 9).

Sejak pertengahan abad dua puluh, diskursus tentang tasawuf mampu menarik perhatian para pemikir timur maupun barat, bahkan mengalahkan perhatian mereka terhadap pemikiran-pemikiran para teolog Islam dan para filusuf Arab, baik yang berada di Arab bagian timur seperti Al Farabi dan Ibnu Sina ataupun di Arab bagian barat seperti Ibnu Bajah, Ibnu Tufail dan Ibnu Rusyd. Lahan kajian tasawuf masih berjuta-juta hektar dan hampir bisa dikatakan masih "perawan", terlebih jika kita melihat ribuan karya yang ditinggalkan para teosof Islam baik yang sudah tercetak maupun yang berupa manuskrip masih membutuhkan perhatian dan kajian yang mendalam (Salim, 2005: 2). Salah satu penyebab ketidakpedulian para pemikir Islam terhadap tasawuf adalah nalar mayoritas yang mengatakan bahwa intuisi sufistik adalah bunga mimpi, igauan dan perkataan mereka adalah ungkapan kosong tanpa 
arti. Sungguh fenomena yang menyedihkan, andai mereka mau bersikap adil dalam melihat tasawuf dengan tanpa mendahulukan apriori, maka mereka akan mempunyai pandangan yang berbeda tentang tasawuf.

Kaum sufi menapaki jalan yang berbeda untuk menuju hakikat, mereka tidak menggunakan akal dan rasio untuk sampai pada hakikat. Akan tetapi, apakah kita mempunyai argumen yang meyakinkan bahwa akal adalah satu-satunya jalan untuk menuju hakikat? Bukankah kita sering melihat sesuatu yang di luar jangkauan akal dalam hidup ini? Jalan yang ditempuh kaum sufi untuk menuju hakikat seperti kasyf, dzauq, 'iyan, dan musyahadah adalah sesuatu yang dianggap samar, tidak mempunyai batasan dan kaidah pasti, bahkan sering kali bercampur dengan igauan, mimpi, khayalan dan angan-angan. Tapi yang perlu diingat adalah media-media tersebut mampu menuntun manusia untuk memecahkan sesuatu yang tidak bisa dipecahkan oleh akal dan hukum-hukum fisika (Badawi, 1969: 116). Maka, tidak salah jika media-media sufistik tersebut digunakan untuk memecahkan masalah yang tidak mampu dijawab oleh akal. Paparan di atas kiranya cukup untuk menjadi motivasi bagi penulis untuk memberikan ulasan tentang beberapa tokoh tasawuf dan gagasan-gagasannya.

Dalam tulisan ini penulis akan mengangkat aliran dan gagasan-gagasan yang kerap menjadi perdebatan di kalangan umat Islam, yaitu tentang cinta Ilahi (al hubb al ilahi), pantheisme (wahdat al wujud), wahdat al yuhud dan wahdat al adyan yang diusung oleh dua tokoh besar yaitu Ibnu al Farid dan Ibnu Arabi yang hidup pada abad keenam dan ketujuh Hijriah.

\section{Pembahasan}

\section{Biografi Ibnu al Farid dan Ibnu Arabi}

Para penulis biografi Ibnu al Farid sepakat bahwa nama panjang beliau adalah Abu Hafs dan Abu al Qosim Umar bin Abi al-Hasan Ali bin Mursyid bin Ali, beliau dikenal dengan nama Ibnu al-Farid karena ayah beliau adalah seorang pengacara yang selalu membela kaum hawa di pengadilan untuk mendapatkan bagiannya (al-furudh) atas suaminya, sehingga ayah beliau dijuluki al-Farid. Kemudian putranya dikenal dengan julukan Ibnu al Farid. Ibnu al-Farid lahir 4 Dzul Qa'dah 576 H/1181 M (Hilmi, tt: 29-32). Beliau menghabiskan hampir seluruh hidupnya di Mesir, dan meninggal pada Selasa dua Jumad al-Ula 632 H/1234 M (Hilmi, tt:18-32).

Selanjutnya penulis ingin sedikit memaparkan tentang kondisi sosial, ekonomi dan politik di mana Ibnu al Farid hidup, karena kondisi tersebut 
mempunyai andil dalam pembentukan karakter dan jiwa sufi Ibnu al-Farid. Beliau hidup pada dua abad sekaligus; yakni seperempat abad terakhir dari abad keenam, dan sepertiga awal dari abad ketujuh Hijriah. Pada masa itu terjadi peralihan kekuasaan besar-besaran. Mesir dan Syam yang sebelumnya di bawah kekuasaan Fatimiyah berpindah ke tangan Ayubiyah. Ini artinya, undang-undang agama di Mesir dan Syam yang sebelumnya mengikuti madzhab syiah berpindah haluan menuju ahlussunnah. Pada masa itu pula perang salib berkecamuk, menimbulkan keprihatinan dan kesusahan, sehingga Mesir mengalami krisis yang tak berujung. Pada tahun 598-599 H, air sungai Nil mengalami surut sehingga menyebabkan merosotnya hasil pertanian, wabah menyebar, dan situasi keamanan begitu mengkhawatirkan. Meskipun demikian, tradisi keilmuan terus mengalami perkembangan yang cukup signifikan karena penguasa-penguasa Mesir mulai dari Sholahuddin al Ayyubi, Aziz, Adil dan Kamil adalah orang-orang yang cinta akan ilmu, sastra, sunnah dan tasawuf. (Hilmi, tt: 37-41).

Pada abad yang sama, lahir seorang wali agung yang gagasan-gagasan filsafat dan tasawufnya mempunyai pengaruh yang cukup luas. Beliau adalah Abu Abdillah Muhyiddin Muhammad bin Ali bin Muhammad bin al Arabi al Hatimi atau yang lebih dikenal dengan Ibnu Arabi. Beliau lahir 17 atau 27 Ramadan (ulama berselisih pendapat seputar tanggal kelahiran Ibnu Arabi) 560 H/1165 M di Marsiyah, Andalus atau Spanyol. Sejak berumur delapan tahun, Ibnu Arabi bersama keluarganya hijrah ke Espilia dan mulai belajar al Quran, hadits dan fikih di Qortoba dari murid-murid Ibnu Hazm al Dzahiri $(456 \mathrm{H})$. Pada usia tiga puluh tahun, beliau pergi mengunjungi beberapa kota di Andalus dan Maroko, dan tak lupa belajar tasawuf dari tokoh-tokoh sufi setempat seperti Abu Madyan al Ghouts al Talmasani. Pada $620 \mathrm{H}$ beliau berkunjung ke Tunis, Hijaz, Yaman, Syam, Iraq, Mesir, dan menetap di Damaskus. Beliau meninggal pada 638 H (Karim, 2004: 18).

Kondisi sosial dan politik di Andalusia tidak jauh berbeda dengan kondisi di Mesir. Peperangan berkecamuk di dunia Arab belahan barat maupun timur. Pada 591 H/1195 M, di Andalusia terjadi perang Alarcos yang dimenangkan oleh umat Islam. Kemudian pada 609 H/1212 M terjadi perang Las Navas de Tolos (al 'Iqob) yang dimenangkan oleh kaum Nasrani. Sedangkan di dunia Arab bagian timur, perang salib mencapai puncaknya, Pada 583 H/1187 M, Shalahuddin al Ayyubi berhasil merebut al Quds, kemudian disusul dengan perang salib keempat dan kelima hingga pada akhirnya bangsa Eropa mampu merebut kembali al Quds pada 624 H/1229 M (Zaid, 2002: 66) . 
Berbagai peperangan yang terjadi di daerah-daerah Ibnu Arabi dan Ibnu al Farid hidup, berdampak pada carut-marutnya kondisi sosial dan politik di daerah tersebut. Hal tersebut mendorong sebagian orang -termasuk Ibnu Arabi dan Ibnu al Farid untuk menjauhkan diri dari hal-hal duniawi. Dunia tasawuf lah yang menjadi pilihan kedua sosok tersebut. Hasil pemikiran dan renungan sebagai sufi tersebut tidak hanya dipraktikkan dalam kehidupan sehari-hari, namun juga dituangkan dalam tulisan-tulisan oleh Ibnu Arabi dan Ibnu al Farid, sehingga kita bisa melihat dan mengambil pelajaran yang sangat berharga dari karya-karya mereka.

\section{Cinta Ilahi (al Hubb al Ilahi)}

Sejarah tasawuf menyebutkan bahwa tradisi kehidupan sepiritual dalam Islam di masa awal munculnya adalah ungkapan rasa zuhud yang menyelimuti diri kaum sufi. Pada tahun sekitar 40-110 H, aliran tasawuf telah menyebar ke Basrah, Kufah dan Madinah. Pada masa itu, hal yang mendorong rasa zuhud para sufi lahir dari rasa takut akan neraka dan keinginan untuk masuk surga. Salah satu tokohnya adalah Hasan al Basri (21-110 H). Sya'rani melukiskan Hasan al-Basri sebagai orang yang selalu diselimuti rasa takut sampai seakanakan neraka diciptakan hanya untuknya (Hilmi, tt: 139).

Seiring berjalannya waktu, tradisi kehidupan sepiritual mengalami lonjakan-lonjakan. Kehidupan sepiritual tidak lagi dikendalikan oleh rasa takut akan neraka dan keinginan masuk surga, akan tetapi oleh rasa cinta yang tulus kepada Allah SWT. Cinta tanpa mengharapkan imbalan kecuali mendambakan untuk melihat Dzat Allah SWT dan keindahan-Nya yang abadi, dan menjadikan cinta ini sebagai tujuan hidup. Rabiah al Adawiyah (w. 185 $\mathrm{H}$ ), yang telah membawa rasa cinta ini ke dalam tradisi kehidupan sepiritual Islam. Hal ini senada dengan pendapat Massignon yang mengatakan bahwa Rabiah al-Adawiyah telah meninggalkan warisan yang sangat berharga bagi tradisi kehidupan sepiritual Islam, menggunakan kata cinta (al hubb) dengan tegas dan lantang untuk mengungkapkan rasa rindu dan cinta Ilahinya dengan berlandaskan pada al Quran (QS al Maidah: 53). Pada masa Rabiah, banyak kaum sufi yang menyanyikan lagu cinta dan rindu, tapi tidak satupun dari mereka yang mendahului Rabiah dalam menggunakan kata cinta (al hubb) secara jelas untuk mengungkapkan rasa cintanya kepada Allah SWT, sebagaimana tertuang dalam syair Rabiah al Adawiyah yang masyhur:

Uhibbuka hubbaini: hubb al hawa wa hubban liannaka ahlun lidzaka Fa amma al ladzi huwa hubb al hawa fa syughli bidzikrika 'amman siwaka 
Wa amma al ladzi anta ahlun lahu Fala al hamdu fi dza wa la dzaka li fa kasyfuka li al hajba hatta araka walakin laka al hamdu fidza wadzaka

Sepeninggal Rabiah, kaum sufi berbondong-bondong mengungkapkan rasa rindu dan cinta mereka dengan kata cinta yang jelas, seperti Ma'ruf al Kurkhi (w. 200/201 H), al Junaid (w. 297 H), al Muhasibi (w. 243 H), Dzu al Nun al Mishri (w. 245 H), Yahya Ibnu Mu'adz al Rozi (w. 258 H), selanjutnya disusul oleh al Hallaj (w. 309 H) (Hilmi, tt:142). Maka, lahirlah puisi-puisi cinta Ilahi sebagai karya sastra beraroma tasawuf dan filsafat yang tak ternilai, dirangkai oleh kaum sufi untuk mengungkapkan rasa rindu yang menyelimuti. Dalam puisi-puisi tersebut, tak jarang ditemukan ungkapan kata tentang cinta, arak dan hal-hal lain yang berhubungan dengan keduanya, sehingga sulit untuk membedakan antara puisi orang yang sedang mabuk cinta kepada seorang manusia, mabuk arak dan mabuk cinta Ilahi. Hal inilah yang menyebabkan penyair-penyair sufi mendapatkan tuduhan-tuduhan miring yang sangat berlebihan. Ibnu al Farid misalnya, dituduh oleh orang-orang Eropa sebagai penyair yang gemar meminum arak dan mabuk-mabukan, sedangkan Ibnu Arabi dituduh oleh tokoh-tokoh agama Islam sendiri sebagai orang yang fasik, kafir dan lain sebagainya (Hilmi, tt: 144).

Ibnu Arabi dan Ibnu al Farid mengikuti aliran cinta Ilahi yang diusung oleh kaum sufi sebelumnya dan dipelopori oleh Rabiah al Adawiyah. Teori cinta Ilahi Ibnu Arabi mengacu pada wahdat al wujud. Ibnu Arabi menyampaikan rasa cintanya dalam syair-syair yang terkumpul dalam karyanya Turjuman al Asywaq yang disusun ketika beliau berada di Mekah. Beliau menceritakan pertemuannya dengan seorang syaikh yang bernama Makinuddin Abi Syuja' Zahir al Asfihani. Al Asfihani mempunyai seorang putri bernama Nidzam, ia sangat cantik wajah dan pekertinya, dan memikat hati Ibnu Arabi. Kemudian ia merangkai sekumpulan syair untuk mengungkapkan cinta Ilahinya. Dalam syair-syair itu ia mengulang-ngulang nama, rumah, pekerti dan hal-hal lain yang berhubungan dengan gadis tersebut. Ibnu Arabi dalam Dazkhairu al A'alaq syarh Turjuman al Asywaq menyebutkan hal-hal yang berhubungan dengan sang gadis dengan kinayah untuk mengungkapkan cinta Ilahinya (Mahmud, 1969: 71). Terlepas dari perbedaan ulama seputar syair-syairnya dalam Turjuman al Asywaq; apakah syair-syair tersebut sungguh ditujukan kepada Tuhannya ataukah kepada seorang gadis yang sangat menawan dan pernah memikat hatinya?

Dalam al Futuhat al Makkiyah, Ibnu Arabi menjelaskan bahwa seseorang 
yang sedang dilanda cinta Ilahi, ia tidak akan dimintai pertanggungjawaban di hadapan Tuhan atas segala perbuatannya di dunia. Beliau berdalih bahwa orang yang sedang mabuk cinta akan hilang akalnya dan tidak mempunyai kekuatan untuk memilih mana yang baik dan mana yang buruk, sedangkan jaza' atau pertanggungjawaban adalah bagi hamba yang mempunyai akal dan kekuatan untuk menentukan pilihan. Orang yang sedang mabuk cinta Ilahi seperti kaum ahlu badr yang Allah SWT mengampuni dosa dan mengizinkan mereka untuk melakukan segala sesuatu sekehendak mereka. Ibnu Arabi menambahkan bahwa orang yang sedang mabuk cinta Ilahi tak ubahnya seperti orang gila yang segala perbuatannya, baik itu perbuatan baik ataupun buruk tidak terkena hisab (Al Thawil, 1969: 170) .

Sama halnya dengan Ibnu Arabi, Ibnu al Farid juga merupakan penyair sufi berkebangsaan Arab penganut agama cinta Ilahi yang mewariskan sastra beraroma tasawuf dan filsafat. Memang secara kuantitas peninggalan Ibnu al Farid tidaklah seberapa bila dibandingkan dengan peninggalan para penyair dari Persia seperti Jalaluddin al Rumi, Fariduddin al 'Atthar atau Hafidz al Syairazi. Tapi meskipun kecil secara kuantitas, peninggalan tersebut merupakan tradisi sepiritual yang mampu menarik perhatian kalangan kaum sufi, sastrawan atau bahkan filosof baik dari timur maupun barat dari dulu sampai sekarang. Sekaligus sebagai sumbangan peradaban dari Arab untuk mengimbangi kekayaan sastra persia.

Adapun teori Ibnu al Farid dalam cinta Ilahi tercakup dalam dua kumpulan syairnya yang tersohor yaitu al Ta'iyah al Kubra (Nadzm al Suluk) yang berjumlah tujuh ratus enam puluh satu syair, dan al Mimiyah (al Khumriyah). Dengan mengecualikan beberapa bait yang beraroma wahdat al-wujud dari syair Ibnu al Farid dalam nadzm al suluk, bisa dipastikan bahwa Ibnu al Farid adalah seorang sufi yang teori cinta Ilahinya mengikuti aliran wahdat al syuhud, karena Ibnu al Farid tidak mengikuti retorika mantiq dan filsafat -sebagaimana yang dilakukan Ibnu Arabi dalam sebagian besar karyanya seperti membuat premispremis kemudian mengambil konklusi, memberikan analisa-analisa filosofis dan mentakwil ayat-ayat al Quran dan hadits dengan berbagai metodologi interpretasi, agar sesuai dengan alirannya. Ibnu al Farid hanya berpasrah dan mengikuti arus cintanya, hilang dari dirinya sendiri dan dari segala sesuatu di sekitarnya sehingga tidak mampu melihat sesuatu kecuali melihat Allah SWT di dalamnya. Terkadang beliau melewatkan suatu masa sampai berhari-hari lamanya tanpa makan, minum dan bicara. Ia hanya terbaring seperti mayat dan matanya menatap tajam ke arah langit. Ketika tersadar dan mencapai fase 
fana, ia mulai menyampaikan dan melantunkan bait-bait al Taiyah al Kubra yang ia terima dari Allah SWT.

Kilana mushallin wahidun sajidun ila Wama kana li shalla siwaya walam takun

haqiqatihi bi'l jam'i fi kulli sajdatin shalati lighairi fi ada' kulli rak'atin

Dua bait di atas adalah ungkapan yang paling berani dan tajam dari Ibnu al Farid dalam al Taiyah al Kubra, yang kemudian dijadikan bukti bagi "musuh-musuh" nya untuk mengatakan bahwa Ibnu al Farid adalah penganut wahdat al wujud (Afifi, 1963: 228-331).

Ibnu al Farid membagi cinta Ilahi menjadi dua macam. Pertama, cinta seorang hamba kepada Tuhannya sebagaimana telah diuraikan di atas, dan diterangkan panjang lebar dalam al Taiyah al Kubra. Kedua, cintanya Allah SWT untuk diketahui (hubbullahi lian yu'rafa) yang diterangkan dalam al Mimiyah. Ibnu al Farid dalam memaparkan cinta Ilahi jenis kedua berusaha mengajukan format hubungan antara cinta dan penciptaan alam, dan makhluk itu wujud karena adanya cinta. Hal ini sesuai dengan firman Allah SWT dalam hadis qudsi yang berbunyi : "Kuntu kanzan makhfiyyan, fa ahbabtu an u'rofa, fa khalaqtu al khalqa fa bihi 'arafuni”. Menurut Ibnu al Farid, Cinta disini adalah sumber kehidupan. Adapun hakikat cinta ini bukan sesuatu yang matrialistik, ada sejak zaman azali pada suatu alam, dan akan tetap ada sampai akhir nanti, karena ia abadi. Cinta ini tidak berdiri di atas sesuatu akan tetapi segala sesuatulah yang berdiri di atasnya (Hilmi, tt: 172-175).

Setelah pemaparan singkat tentang tradisi kehidupan sepiritual dalam Islam yang dimulai dari Hasan al Basri, kemudian disusul Rabiah al Adawiyah yang memunculkan gagasan tentang al hubb al Ilahi yang kemudian diikuti oleh kaum sufi setelahnya termasuk Ibnu Arabi dan Ibnu al Farid. Penulis akan menjelaskan teori wahdat al wujud (pantheisme) dan wahdat al syuhud (panentheisme) menurut Ibnu Arabi dan Ibnu Farid.

\section{Wahdat al Wujud dan Wahdat al Syuhud}

Wahdat al wujud adalah teori yang mengatakan bahwa yang ada itu hanya satu yaitu wujud Allah SWT, tidak ada wujud yang hakiki selain wujud Allah SWT, segala sesuatu yang tampak oleh indra kita selain wujud Allah SWT adalah nihil dan sebatas khayalan yang muncul karena keterbatasan akal (Karim, 2004: 68). Adapun wahdat al syuhud adalah suatu keadaan seorang sufi tidak lagi mampu melihat sesuatu kecuali wujud Allah SWT dengan tetap mengakui eksistensi wujud selain Allah SWT. Wahdat al wujud ditetapkan oleh 
akal sehingga wahdat al wujud bisa muncul dari semua orang, baik sufi atau tidak, berbeda halnya dengan wahdat al syuhud yang merupakan fenomena khusus kehidupan spiritual dan hanya muncul dari seorang sufi.

Ibnu Arabi adalah bapak teori wahdat al wujud (pantheisme). meskipun ide-ide tentang wahdat al wujud sering dimunculkan para teosof sebelum Ibnu Arabi, namun di tangan Ibnu Arabi, teori wahdat al wujud mencapai bentuk yang sempurna. Beliau mempunyai jasa besar karena telah menguraikan berbagai hal berkaitan dengan teori wahdat al wujud terutama dalam dua karya agungnya yaitu al Futuhat al Makkiyah dan Fusus al Hikam. Teori wahdat al wujud tidak pernah terpisah dari nama besar Ibnu Arabi. Meski demikian, Ibnu Arabi tidak pernah menyebutkan atau menulis secara jelas kata-kata wahdat al wujud dalam karya-karyanya, justru Ibnu Timiyah-lah orang yang pertama kali menggunakan istilah ini. Sepeninggal Ibnu Arabi, tidak seorangpun yang mampu berbicara tentang teori wahdat al wujud kecuali ia di bawah pengaruh Ibnu Arabi atau menukil darinya atau hanya mengulang-ulang satu substansi dalam bentuk kalimat yang berbeda-beda (Afifi, 1963: 187) .

Hanya saja sejak masa kemunculan wahdat al wujud Ibnu Arabi sampai sekarang, banyak kalangan yang berusaha menafikan atau memisahkan wahdat al wujud dari Ibnu Arabi dengan anggapan bahwa wahdat al wujud adalah teori matrealistik dan sesat yang tidak mungkin muncul dari seorang wali Allah SWT. Teori Ibnu Arabi bukanlah wahdat al wujud matrealistis yang mengatakan bahwa wujud yang hakiki hanyalah alam yang tampak oleh indra kita, justru sebaliknya Ibnu Arabi mengatakan bahwa wujud yang hakiki adalah wujud Tuhan al Haq yang menampakkan dirinya dalam alam semesta, jadi wujud alam adalah sebatas bayang-bayang bagi wujud yang hakiki (Afifi, 1963: 187,196).

Ibnu Arabi memandang bahwa tidak ada yang wujud kecuali Allah SWT. Dia wujud yang hakiki, wujud yang absolut, azali dan abadi. Jadi, wujud yang hakiki hanyalah satu dan tak berbilang. Sedangkan fenomena berbilangnya sesuatu atau wujud dalam alam yang ditangkap oleh indra manusia hanyalah gambar-gambar atau tempat-tempat dimana sifat-sifat Allah SWT yang merupakan dzat Allah SWT sendiri menampakkan diri-Nya, atau hanya khayalan yang muncul karena keterbatasan indra dan akal. Maka, tidak ada perbedaan sama sekali antara Tuhan dengan Makhluk-Nya atau antara Pencipta dengan yang diciptakan kecuali dari sudut pandang saja. Apabila dilihat dari sisi ke-Esaan-Nya, Dia adalah al Haq, dan jika dilihat dari sisi berbilangnya, Dia adalah makhluk. Keduanya (al Haq dan makhluk) adalah dua nama untuk satu hakikat (Madkur, 1969: 370). Dalam kerangka wahdat 
al wujud, Ibnu Arabi tidak mempercayai adanya cretion ex-nihilo (alam pernah diciptakan dari tidak ada pada suatu masa), yang ada hanya emanation artinya Allah SWT telah menampakkan segala sesuatu di alam dari wujud-Nya yang azali menjadi wujud yang nyata dan tampak (Karim, 2004: 69).

Ibnu Arabi pada sisi lain dinilai sebagai pengikut aliran wahdat al syuhud , hal ini terbukti dari lampiran al Futuhat al Makkiyah (bab 252) atau dalam kitab al Jalalah. Jadi, Ibnu Arabi tidak hanya beraliran wahdat al wujud, beliau juga beraliran wahdat al syuhud sebagaimana al Hallaj dan Ibnu al Farid. Hanya saja, sisi yang pertama lebih dominan dari pada sisi yang kedua (Hilmi, tt: 318).

Hal serupa juga terjadi pada Ibnu al Farid. Sebagian ulama mengatakan Ibnu al Farid merupakan penganut wahdat al wujud yang pemikirannya lebih didominasi oleh teori akal dari pada intuisi sepiritual. Sebagian ulama lain mengatakan Ibnu al Farid merupakan penganut wahdat al syuhud. Jika membaca syair-syair Ibnu al Farid secara seksama dan memperhatikan kondisi jiwa dan spiritualnya, dapat disimpulkan bahwa Ibnu al Farid adalah penganut aliran wahdat al syuhud. Meskipun, beliau sering terlihat mencampuradukkan alirannya dengan unsur-unsur tasawuf dan filsafat orang lain untuk menciptakan kombinasi tasawuf baru.

Di satu sisi, Aliran Ibnu al Farid adalah peniadaan diri (fana') dari melihat sesuatu selain Allah SWT, artinya ia tidak menafikan eksistensi wujudnya sesuatu selain Allah SWT di alam nyata, hanya saja ia mengingkari atau tidak mampu melihat sesuatu tersebut dengan panca indra. Di sisi lain, aliran Ibnu al Farid adalah fana' dari kehendak (iradah) sesuatu selain Allah SWT, artinya ia tidak lagi mempunyai kehendak karena ia telah melebur kehendaknya dengan kehendak Kekasihnya. Dari dua fana' tersebut, dapat disimpulkan bahwa keduanya sebatas perasaan jiwa seorang sufi yang menyatu dengan Tuhannya, dan bahwa aliran Ibnu al Farid jauh berbeda dengan teori wahdat al wujud yang merupakan peniadaan diri atau fana' dari eksistensi segala sesuatu selain Allah SWT, yang berarti menafikan eksistensi wujud segala sesuatu selain Allah SWT, serta Allah SWT dan alam adalah satu. Maka sangatlah tepat jika dikatakan Ibnu al Farid lebih condong dengan wahdat al syuhud atau panentheisme, daripada wahdat al wujud atau pantheisme (Hilmi: 307, 310). Secara substantif, Ibnu al Farid bukan seorang filosof, bukan juga seorang ahli mantik yang selalu menggunakan rasio dalam segala hal. Beliau lebih tepat disebut penyair sufi yang lebih mengandalkan intuisi spiritual, perasaan dan emosional yang kuat yang mengantarkannya menuju wahdat al 
syuhud (Hilmi, tt: 311 ).

Setelah uraian singkat tentang wahdat al syuhud dan wahdat al wujud menurut Ibnu al Farid dan Ibnu Arabi di atas, penulis akan mengulas hal yang tak kalah penting dan menariknya, yaitu wahdat al adyan versi kedua tokoh tersebut, karena wahdat al adyan adalah sesuatu yang lazim atau akibat yang pasti dan otomatis bagi seseorang yang meyakini keesaan wujud (al wahdah).

\section{Wahdat al Adyan}

Ibnu al Farid dan Ibnu Arabi dalam wahdah al adyan bisa dikatakan sepakat dengan kaum sufi lainnya, teori ini berpandangan bahwa pada hakikatnya agama-agama itu hanya satu, dan kesemuanya adalah milik Allah SWT. Al Hallaj merupakan orang yang pertama kali melontarkan gagasan ini, menurutnya semua agama adalah milik Allah SWT dan agama Islam, Nasrani, Yahudi dan agama lainnya hanya nama dan sebutan yang berbeda-beda dan berubah-ubah, adapun substansi dan tujuannya adalah satu dan harga mati. Pemikiran al Hallaj ini, kemudian menitis kepada kaum-kaum sufi setelahnya dan berkembang sesuai dengan madzhab masing-masing, sampai akhirnya wahdat al adyan menjadi suatu kelaziman yang muncul sebagai akibat dari keyakinan tentang keesaan wujud.

Cinta Ilahi yang menyelimuti sosok Ibnu al Farid tidak hanya mengantarkannya menuju wahdat al syuhud, tapi juga membawanya berpandangan bahwa agama dan keyakinan yang berbeda-beda itu hanyalah kulit luarnya saja. Adapun dari segi substansi dan hakaikat, tidak ada perbedaan sama sekali. Agama-agama tersebut tidak lain hanyalah sebatas mediator-mediator untuk menuju satu tujuan yang sama yaitu menyembah Tuhan yang maha Esa. Lebih jauh, Ibnu al Farid mengajarkan bagaimana menyikapi perbedaan agama. Menurutnya, agama mayoritas tidak patut memojokkan yang minoritas, tidak membedakan antara satu agama dengan lainnya, tidak memuliakan satu kitab suci dan memaki lainnya, tidak fanatik terhadap satu kelompok dan meninggalkan lainnya, karena semua agama adalah milik Allah SWT. Ibnu al Farid menambahkan bahwa seseorang yang memeluk suatu agama tidaklah karena ia memilih agama tersebut, melainkan Allah SWT-lah yang mentakdirkan orang itu memilih agama tersebut (Hilmi, tt: 382).

Ibnu al Farid membangun teori wahdat al adyan atas tiga pemahaman: pertama, pemahaman bahwa semua agama itu sama secara substantif, meskipun berbeda-beda pada dzahirnya. Karena semua agama mengajak untuk beribadah pada satu Tuhan meski bentuk dan model ibadahnya berbeda-beda. Jadi tidak 
ada beda antara agama-agama yang mengajak menyembah satu Tuhan dengan agama yang mengajak menyembah dua atau tiga Tuhan. Iman dan kufur tidaklah berbeda secara substantif, seorang yahudi, nasrani, muslim, majusi dan penyembah berhala, mereka sama-sama menyembah satu Tuhan, hanya bentuk ibadahnya saja yang berbeda. Majusi misalnya, pada hakikatnya bukan api yang mereka sembah, melainkan karena mereka pernah melihat cahaya dzat Ilahi yang dianggapnya api, kemudian mereka menyembahnya. Kedua, pemahaman bahwa manusia tidak mempunyai kehendak dan pilihan untuk menentukan sesuatu (jabariyah), karena semua sudah ditentukan oleh Allah SWT, termasuk pilihan akan menjadi mukmin atau kafir. Dengan demikian, orang yang tersesat dan tidak mendapatkan petunjuk untuk mengetahui Tuhan, sebenarnya tidaklah lebih buruk dari orang yang mendapatkan petunjuk, karena Allah SWT yang memberikan petunjuk dan menyesatkan siapa saja yang dikehendaki-Nya, dan semua itu berjalan sesuai undang-undang Ilahi yang telah ditetapkan sejak zaman azali. Ketiga, pemahaman bahwa keyakinan terhadap Tuhan yang maha Esa sekaligus sebagai sumber petunjuk dan segala kebajikan adalah keyakinan yang salah, karena akan mendorong orang untuk mejadikan satu Tuhan lagi sebagai sumber kesesatan dan segala bentuk keburukan (Hilmi, tt: 383-388).

Al Hallaj tidak mewariskan wahdat al adyan kepada Ibnu Al Farid saja, namun juga kepada Ibnu Arabi. Secara umum, Ibnu Arabi mempunyai pandangan yang sama dengan Ibnu al Farid yaitu semua agama pada hakikatnya satu dan perbuatan manusia sekaligus pilihannya telah ditakdirkan oleh Allah SWT. Ibnu Arabi menjelaskan bahwa orang yang beriman di dunia sebenarnya ditakdirkan untuk menjadi orang mukmin sejak zaman azali, begitu juga dengan orang yang kafir. Lebih jauh, Ibnu Arabi menjelaskan bahwa Allah SWT ada dalam setiap bentuk yang dibayangkan manusia sebagaimana Allah SWT itu ada dalam setiap bentuk yang tidak dibayangkan manusia. Maka, setiap keyakinan mempunyai sisi kebenaran sebagaimana orang yang berseberangan dengan keyakinan tersebut juga mempunyai sisi kebenaran tersendiri. Hal ini karena Allah SWT menampakkan diri-Nya dalam setiap bentuk yang diyakini oleh semua makhluk-Nya. Meski demikian, Allah SWT tidak akan pernah disembah dalam bentuk yang semestinya, Allah SWT hanya akan disembah dalam bentuk yang dijadikan oleh Allah SWT dalam diri seorang hamba (Salim, 2005: 233). 


\section{Simpulan}

Dari kajian di atas, dapat disimpulkan bahwa gagasan-gagasan Ibnu Arabi dan Ibnu al Farid terkait al hubb al Ilahi, wahdat al wujud, wahdat al syuhud dan wahdat al adyan adalah sebagai berikut:

Pertama, teori cinta Ilahi Ibnu Arabi mengekor pada teori umumnya yaitu wahdat al wujud. Menurutnya, seseorang yang sedang dilanda cinta Ilahi, tidak dimintai pertanggungjawaban di hadapan Tuhan atas segala perbuatannya di dunia. Karena orang yang sedang mabuk cinta akan hilang akal, sedangkan pertanggungjawaban (jaza') hanya diperuntukkan bagi yang mempunyai akal. Sedangkan Ibnu al Farid, teori cinta Ilahinya mengikuti aliran wahdat al syuhud, Ibnu al Farid hanya berpasrah dan mengikuti arus cintanya, hilang dari dirinya sendiri dan dari segala sesuatu di sekitarnya sehingga tidak mampu melihat sesuatu kecuali melihat Allah SWT.

Kedua: teori wahdat al wujud Ibnu Arabi menjelaskan bahwa wujud yang hakiki adalah wujud Tuhan al Haq yang menampakkan dirinya di alam semesta, Dia wujud yang hakiki, absolut, azali dan abadi. Adapun fenomena berbilangnya sesuatu yang ditangkap oleh indra manusia hanya gambar atau tempat dimana sifat-sifat Allah SWT yang merupakan dzat Allah SWT sendiri menampakkan diri-Nya, atau hanya khayalan yang muncul karena keterbatasan indra dan akal. Sedangkan menurut Ibnu al Farid, satu sisi adalah peniadaan diri atau fana' dari melihat sesuatu selain Allah SWT. Di sisi lain, fana' dari kehendak (iradah) sesuatu selain Allah SWT, artinya ia tidak lagi mempunyai kehendak karena ia telah melebur kehendaknya dengan kehendak Kekasihnya. Dapat disimpulkan, keduanya sebatas perasaan jiwa seorang sufi yang menyatu dengan Tuhannya. Aliran Ibnu al Farid lebih tepat disebut dengan wahdat al syuhud atau panentheisme.

Ketiga: Ibnu al Farid dan Ibnu Arabi berpandangan sama dalam memahami wahdat al adyan. Pada hakikatnya agama-agama itu hanya satu dan kesemuanya adalah milik Allah SWT. Agama-agama tersebut tidak lain hanyalah sebatas mediator-mediator untuk menuju satu tujuan yang sama yaitu menyembah Tuhan yang maha Esa.

\section{Daftar Pustaka}

Afifi, Abu al 'Ala. 1963. al Tasawuf al Tsauroh al Ruhiyah fi al Islam. Kairo: Dar al Ma'arif.

Abu Zaid, Nasr Hamid. 2002. Hakadza Takallama Ibnu Arabi. Kairo: al Haiah al Misriah al Ammah li al Kitab. 
Abdul Karim, Abdul Jalil Ibnu. 2004. Wahdat al Wujud Inda Ibnu Arabi. Kairo: Maktabah al Tsaqafah al Diniyah.

Badawi, Abdurrahman. 1969. al Kitab al Tidzkari Muhyi al Din Ibnu Arabi. Kairo: Dar al Kitab al Arabi.

Hilmi, Muhammad Musthafa. Tanpa tahun. Ibnu al Farid wa al Hubb al Ilahi. Kairo: Dar al Maarif.

Salim, Zaki. 2005. Al Ittijah al Naqdy 'inda Ibnu Arabi. Kairo: Maktabah al Tsaqofah al Diniyah.

Madkur, Ibrahim Bayumi. 1969. Wadat al Wujud baina Ibnu Arabi wa Spinozza. Kairo: Daru'l Kitab al-Arabi.

Mahmud, Zaki Najib. 1969. Thoriqot al Ramzi inda Ibnu Arabi fi Diwani "Turjuman al Asywaq". Kairo: Dar al Kitab al Arabi

Al Thawil, Taufik. 1969. Falsafat al Akhlaq al Sufiyah 'inda Ibnu Arabi. Kairo: Dar al Kitab al Arabi. 